\title{
The Peculiarities of the Budgetary Policy of Georgia and the Directions of Improvement in Association with EU
}

\author{
George Abuselidze ${ }^{1 *}$, Linda Mamuladze ${ }^{1}$ \\ ${ }^{1}$ Batumi Shota Rustaveli State University, Ninoshvili street 35, 6000-6010 Batumi, Georgia
}

\begin{abstract}
The work deals with the role of budgetary policy on socioeconomic development of the country, the practical significance of budgetary policy improvement, the peculiarities of program financing, the problems of rationalization of budget resources, the existing reality and the main directions of improvement the effectiveness. The aspects of research are compared to the advanced international practice. The research is focused on the problems and the anti-rational usage of budget funds in the budgetary process, the peculiarities and efficiency of forming the program budget, the problems in the formation of expected results and budget performance indicators of the programs/sub-programs.
\end{abstract}

Keywords: budget policy, budget planning, program budget, effectiveness, Georgia, EU

\section{Introduction}

Budget planning and project preparation in the program format based on the priorities, which are defined according to the budgetary policy are the most important stages of the budgetary process. Although the preparation of program budget started since 2012 it is still not approved by the Budget Law. Also, the information presented in the program budget needs improvement. Systemic gaps can be noted in the stages of budget planning and reporting, which makes it difficult to compare the planned and achieved results and evaluate the efficiency/rationality of the funds spent from the budget.

The aim of the work is to study and analyze the problems in the process of planning the program budget and implementation of the programs/sub-programs and to elaborate the recommendations.

The objectives of the study were to set the following tasks:

- To study the peculiarities of program financing and evaluate the efficiency of distribution the budget funds;

- To study the existing gaps in the formation the program budget, identify the ways of solving the problems and elaborate the necessary recommendations;

-To analyze the current state of execution the state budget and reveal the modern tendency;

\footnotetext{
*Corresponding author: abuseri@mail.ru / george.abuselidze@bsu.edu.ge
} 
-To compare the aspects of the research to the advanced international practice.

\section{Data and methods}

This research is based on the methods: quantitative, qualitative, statistical, component and comparative analysis and practical approaches, which are in practice and generalized in the Georgian and foreign economic writings and specially touch on the matters of budgetary policy and its effectiveness. The present article is based on the official data of Ministry of Finance of Georgia [21-26], Government of Georgia [37], State Audit Office of Georgia [31-35], The Swedbank [36] and etc.

In the process of writing of the article the scholarly articles by author [2-4] regarding budgetary policies in the regions of Georgia, Staehr [29, 30], Kajaks [10] concerning the socio-economic situation and fiscal policy in the Baltic States during the economic crisis period and Chakvetadze and Khetaguri [7] regarding the result-oriented budgeting have been used. The study of the existing literature on the development of the territorial units as a result is considered that they address the peculiarities and problems associated with the use of the budget policy were mainly considered in the context of accelerating economic growth (Kline and Moretti [11]; Gottlieb and Glaeser [9]; Busso, Gregory and Kline [5]), as well as from the point of view of the development of interbudgetary relations, regional budget or budget policy development in foreign countries (Ehrlich and Seidel [8]; Rodriguez-Pose [28]).

\section{Discussion}

\subsection{The Peculiarities of the Budgetary Policy in the Baltic States}

After gaining the independence Baltic States focused on the market and reducing the role of the government in the economy. The budgetary policy was providing the implementation of private sector supporting programs, the state-limited interventions in various activities and social security issues. This distinguishes the Baltic States economy from other European countries, where the government plays an important role in managing and coordinating the ongoing processes in the economy.

It should be noted that the Baltic States are different from their equal Western European countries and EU15 member states with the number of expenses incurred by the government in relation to GDP (Figure 1).

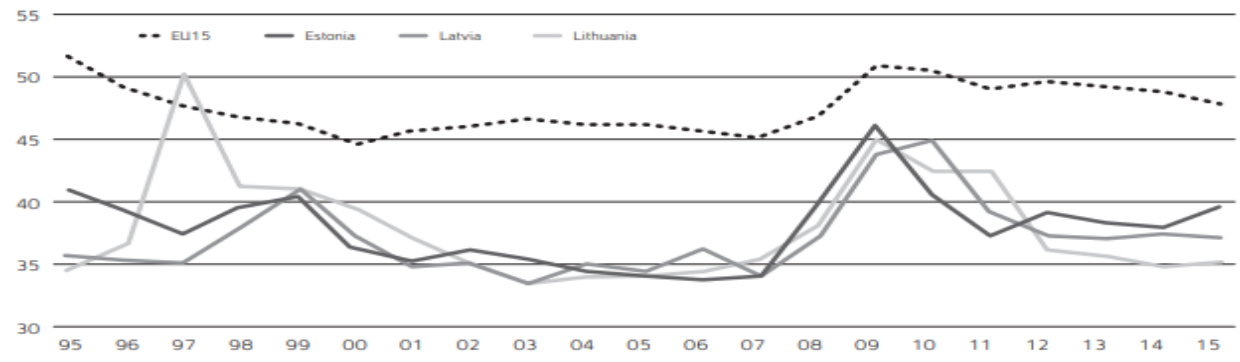

Fig. 1. Government's expenditure in GDP in 1995-2015

Source: Staehr [29]. 
According to Figure 1, a high level of expenses incurred in 1997 in Lithuania is related to compensation of the lost savings by the Government due to the extreme inflation since the beginning of 1990. Also, the government's expenditures in GDP have been significantly increased during the global financial crisis in all three Baltic countries due to the decrease of GDP and in the post-crisis period, as it is shown in the Figure 1, the share of expenditures in GDP is declining rapidly in parallel to GDP growth. Unlike Estonia and Latvia, the share of government's expenditure in GDP in Lithuania is lower (2015), which indicates Lithuania's high economic growth in this period in contrast to other Baltic countries.

The welfare policy of Baltic States is aimed at ensuring children's care, education, health care and the effective functioning of the pension system for people with disabilities and retirement age. A special unemployment insurance system is created in the countries. However, social policy is limited in terms of minimum protection.

Estonia was always adopting a prudent, reasonable fiscal policy while Lithuania and Latvia were facing a significant budget deficit (Figure 2).

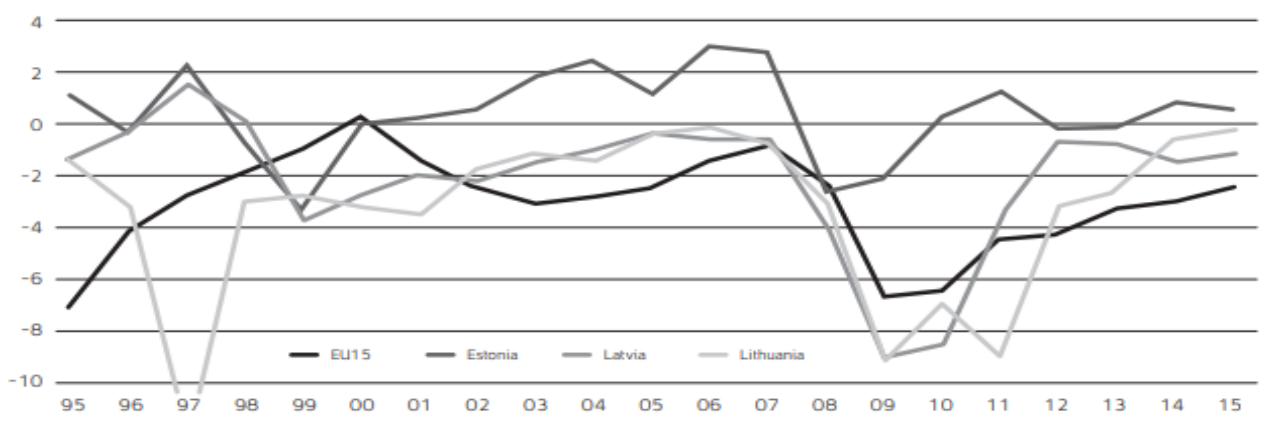

Fig. 2. Fiscal Balance 1995-2015

Source: Staehr [29].

According to Figure 2, for the Baltic States the period 2000-2010 can be divided into two periods: 2000-2007 years - economic boom period and 2008-2010 - economic crisis period. As we can see from the Figure 2, Estonia had a less deficient budget in 2008-2009, but the financial crisis period affected badly on the Lithuanian and Latvian budget, which was characterized by high levels of deficiency.

Despite the global financial crisis, it should be noted the strict policy taken by the Baltic States to get out of the crisis and economic consequences of this policy.

A large part of the budgetary policy was mainly aimed at reducing costs, which meant a significant reduction in employment and wages in public sectors, as well as reductions in social programs and investments [27] and certain structural reforms, such as the combination of schools and hospitals. For example, in Latvia the administrative office of the Ministry of Health decreased by 44\%, many hospitals and 115 schools were closed. $29 \%$ of employees of public services have been released.

However, despite the crisis, all three Baltic states soon got out of the crisis and continued the economic growth process (Figure 3). 


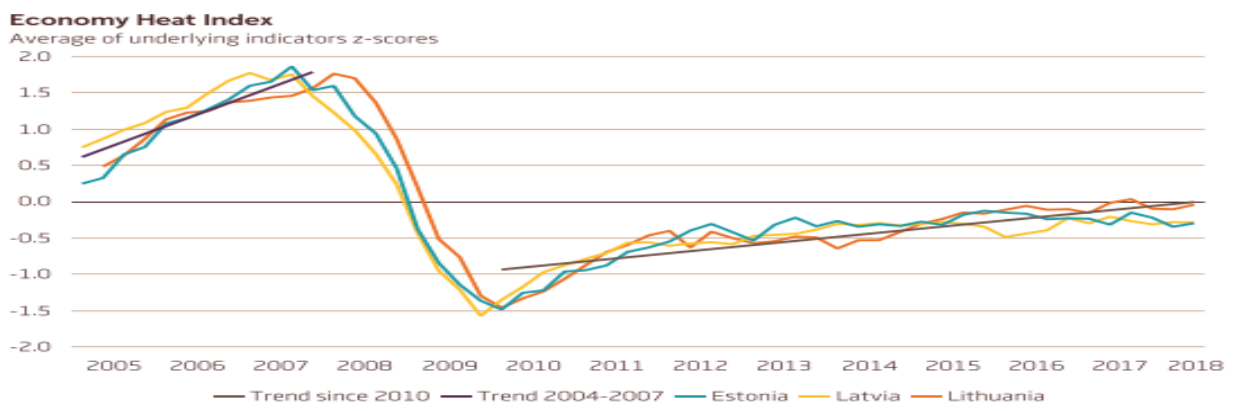

Fig. 3. Economy Heat Index 2005-2018

Source: Swedbank research [36].

From the experience of these countries, the main point of view is that macroeconomic stability can only be achieved by avoiding the excessive economic development and allocation of financial resources and adopting the strict fiscal policy during the economic boom.

\subsection{The Peculiarities of Program Financing in the Budgetary Policy}

The main purpose of the program budget is to implement programs/sub-programs and define their effectiveness by estimating the following correlation "resource $\rightarrow$ product $\rightarrow$ result". Although, it should be noted that increasing resources/expenditures does not always mean an effective budgetary policy due to the gaps during the budget execution process.

By 2014-2017 and 2018 (8 months) the average program implementation rate exceeds $100 \%$ every year (Figure 4 ).

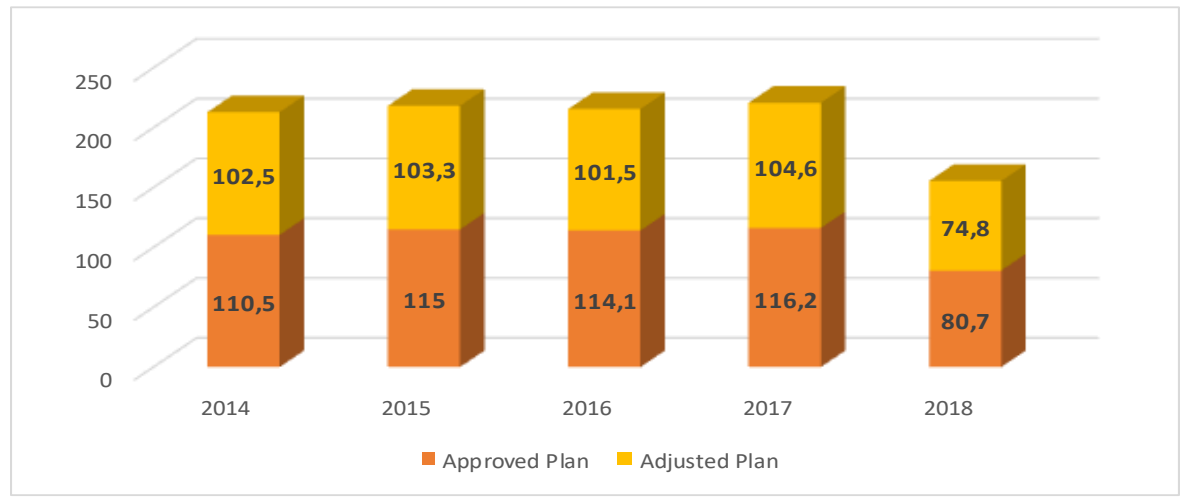

Fig. 4. The Average Program Implementation Rate, 2014-2018

Source: Prepared by author based on the data available in the State Audit Office report, 2014-2018 [31-35].

It must be noted that this data is partially contributed by the direct investment transfers and target grants that do not have a planned performance and are reflected directly in cash expenses.

Hence, we consider it to analyze the program implementation rate with the exception of the unplanned target grants and direct investment transfers, which ultimately changes the original picture (Figure 5). 

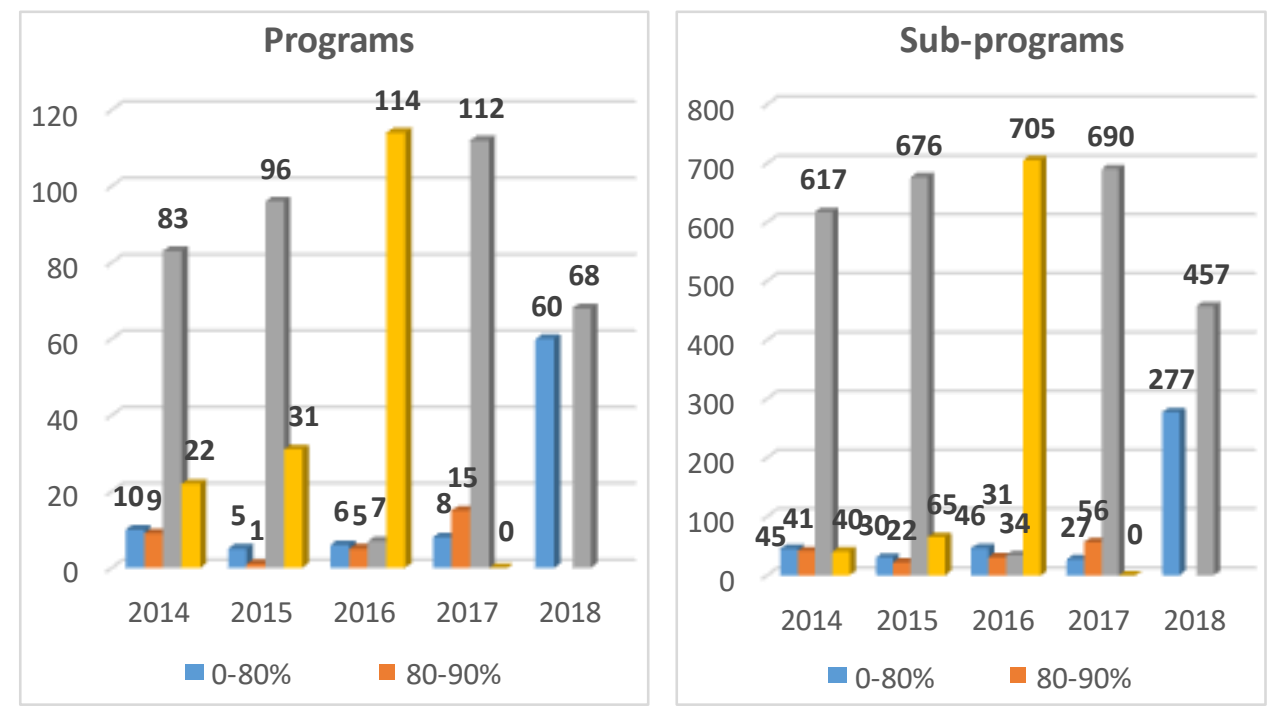

Fig. 5. Programs / Sub-Programs Implementation Rates Regarding to the Adjusted Plan, Excluding the Funds Spent on Target Grants and Direct Investment Transfers

Source: Prepared by author based on the data available in the State Audit Office report, 2014-2018 (2018 - 9 months) [31-35].

As it is shown in Figure 5, the high implementation rate of programs and sub-programs $(>100 \%)$ is growing regarding to the adjusted plan in 2014-2016, in $2017-$ it is between

$90-100 \%$ and in 2018 - the majority of programs and sub-programs have low implementation rate, but the tendency of growth is in $90-100 \%$ interval rate.

However, in case of certain programs/sub-programs despite the high rate of implementation there are still some gaps and low rate of implementation.

In particular, some programs/sub-programs are characterized by the high rate of implementation regarding to the adjusted plan, whereas they have a low rate concerning to the budget plan. This is due to the distribution of funds allocated to other programs that indicates the gaps in the budget planning process. It should also be noted that despite some specification, some of the programs are characterized by low cash flow performance.

For example: on the program "Modernization of irrigation systems" was allocated 71,100 thousand GEL in 2014. However, during the year 21,000 GEL of unused funds were transferred to another program and finally allocation for this program amounted to 50,100 thousand GEL according to the adjusted plan. In this case actual performance $(50,100$ thousand GEL) is $100 \%$ according to the adjusted plan and $70.5 \%$ - according to the budget plan [18]. According to the Article 56 of the "Budget Code of Georgia" [6] the annual report should contain Clarification on the inconsistencies between the approved and adjusted budget allocations for spending institutions, if such inconsistencies exceed $30 \%$. But in this case, the inconsistency is about $29.5 \%$.

A similar tendency is revealed in the following years (Table 1). The table below shows the programs / sub-programs with low rate of performance. 
Table 1. Low Rate Implementation Programs / Sub-Programs

\begin{tabular}{|l|r|r|r|r|c|}
\hline & $\begin{array}{c}\text { Budget } \\
\text { Law (1) }\end{array}$ & $\begin{array}{c}\text { Adjusted } \\
\text { Plan (2) }\end{array}$ & $\begin{array}{c}\text { Cash } \\
\text { Expenditure (3) }\end{array}$ & $\begin{array}{c}3 / 1 \\
\%\end{array}$ & \multicolumn{1}{c|}{$\begin{array}{c}3 / 2 \\
\%\end{array}$} \\
\hline $\begin{array}{l}\text { Provide educational institutions with } \\
\text { information-communication technologies }\end{array}$ & 2,500 & 41 & 41 & $1.6 \%$ & $100 \%$ \\
\hline $\begin{array}{l}\text { Reconstruction and rehabilitation of } \\
\text { Bagdati-Abastumani road }\end{array}$ & 15,000 & 1,680 & 1,679 & $11.2 \%$ & $99.9 \%$ \\
\hline $\begin{array}{l}\text { Development of Public Schools and } \\
\text { Maintenance System }\end{array}$ & 2,000 & 257 & 245 & $12.3 \%$ & $95.5 \%$ \\
\hline
\end{tabular}

Source: Prepared by author based on the data available in the State Audit Office report, (2017) [34].

In some cases, resources are not spent at all which is another problem, as the credit resources consider the payment of a commitment fee on the unused part of the loan and increase the non-purpose expenditures. In order to avoid a similar flow, it is necessary and appropriate to take effective measures by project implementers in order to facilitate the project implementation process.

Especially in 2018 within about 12 programs [19], no funds were spent during 8 months (Table 2). In addition, the total implementation rate of 8 months is less than $60 \%$ for 17 programs and 138 sub-programs.

Table 2. Zero Implementation Programs / Sub-Programs

\begin{tabular}{|l|r|r|r|}
\hline & Budget Law & 9 months adjusted plan & 8 months fact \\
\hline $\begin{array}{l}\text { Supporting agricultural } \\
\text { cooperatives of beekeeping }\end{array}$ & 200 & 200 & 0 \\
\hline Promoting pre-school education & 140 & & 0 \\
\hline $\begin{array}{l}\text { Forest Registration-Inventory } \\
\text { Measures }\end{array}$ & 145 & & 0 \\
\hline
\end{tabular}

Source: Prepared by author based on the data available in the State Audit Office report, (2018) [35].

From 2014-2018 programs "Adjara Solid Waste Project" is especially notable. The credit agreement was signed in 2010, but the implementation of the project and the use of funds has not been started yet (Table 3) and this project is still planned to implement according to 2019 budget.

Table 3. Adjara Solid Waste Project

\begin{tabular}{|c|c|c|}
\hline & Plan & Expenditure \\
\hline 2014 & $2,548,400.0$ & 0 \\
\hline 2015 & $5,000,000.0$ & 0 \\
\hline 2016 & $7,600.0$ & 0 \\
\hline 2017 & $4,000,000.0$ & 0 \\
\hline 2018 & $4,000.0$ & 0 \\
\hline
\end{tabular}

Source: Prepared by the author, based on the reports of the State Audit Office and the reports of the state budget execution [31-35].

As a result, each year commitment fee $(0.5 \%)$ is payed and by the end of 2017 the amount of 154.6 thousand euros was spent, while the credit resource has not yet been applied to the project. 


\subsection{Budget Spending Rationality Problems and the Main Directions of Increasing the Efficiency}

Since the program budget shows the results achieved and not only the allocations used by spending institutions and their budgetary organizations, so during the evaluation process it is necessary to focus on the differences between planned and received results and not only the differences between approved and adjusted budget allocations and cash execution.

In this regard, if we consider the situation in the Autonomous Republic of Adjara in 2015-2018 we will see that the information presented in the Republican Budget Law [1619] of the Autonomous Republic of Adjara and in the Annual Reporting [20, 22, 23, 25] on State Budget Execution is characterized by a number of gaps that makes it difficult to estimate the effectiveness of the program implementation.

The main focus is on identifying the flaws in the process of planning and implementation of programs by the three spending institutions of the region - The Ministry of Agriculture, Department of Tourism and Resorts and Department of Roads and Amelioration Systems Management.

The Figure below provides the information on the number of programs implemented by the Ministry of Agriculture of the Autonomous Republic of Adjara and by its organizations in 2015-2018 (Figure 6).

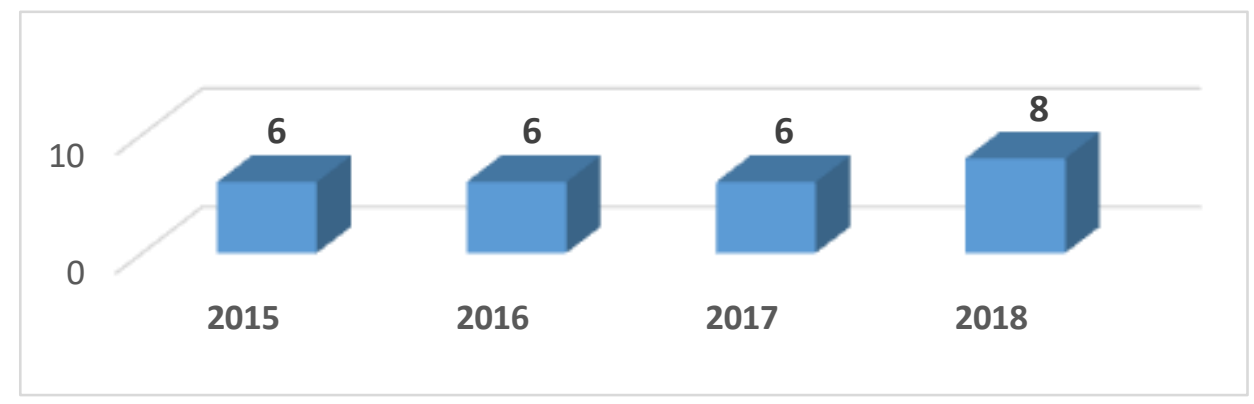

Fig. 6. Programs of the Ministry of Agriculture of the Autonomous Republic of Adjara 2015-2018

Source: Prepared by the author based on the program budget data, 2015-2018 [12-15].

As it is shown on the Figure 6, the Ministry of Agriculture of the Autonomous Republic of Adjara planned 6 projects in 2015-2016, which is confirmed by the program budget of 2015-2016 and the cash execution performed in the Budget Law (Table 4). However, it is noteworthy that the Annual Reporting on State Budget Execution does not include the information about all programs defined by the program budget.

Table 4. Cash Execution of the Programs in 2015-2016, Which are not Available in the Annual Reporting on State Budget Execution

\begin{tabular}{|l|r|r|}
\hline \multicolumn{1}{|c|}{ Name of the program } & Fact of 2015 & Fact of 2016 \\
\hline Development of agroservice in the region & $1,601.3$ & $2,325.0$ \\
\hline Laboratory research services & 338.2 & $1,250.3$ \\
\hline
\end{tabular}

Source: Prepared by the author based on the Republican Budget Law of the Autonomous Republic of Adjara [16, 17].

It should be noted that in the Annual Reporting on State Budget Execution of 20172018 the information about the results achieved in the program "Development of agro service in the Region" is available, but in the case of "Laboratory Research Services" 
program, the information about the achieved results and the progress of the studies is not available.

The similar flaw on the one hand, contradicts the principle of Accountability and Transparency mentioned in Article 4 of the "Budget Code of Georgia" and also the Article 55 and 56 according to which the spending institutions should present the final report to the Ministry of Finance within the established timeframe. The final report must include the information about the programs/sub-programs implemented by spending institutions and the achieved results according to the Article 56. On the other hand, it prevents the effective management of budget resources.

Also, there are number of gaps in the formation of performance indicators for expected and final outcomes. In some cases, the indicators are irrelevant, incorrectly formulated or they are not a measure of effectiveness. Some programs and sub-programs require additional indicators such as quantitative, qualitative, efficient, and productivity indicators in order to ensure that the expected results are correctly evaluated.

One of the expected outcomes of the "Promotion of Livestock Development" is the production of high quality honey and the indicators are - "Transfer the honey extractor to beekeepers and agri-entrepreneur" and "Squeezed honey". The second expected result is the production of "Improved Milk and Dairy Products" and the performance indicators are "Milk separator transferred to farmers and agro-entrepreneurs", "Butter making machine for farmers and agro- entrepreneurs", "Processed milk" and "Produced butter".

In both cases, the indicators are the program implementation plan and do not serve to evaluate its final result, except for the following indicators - "squeezed honey", "processed milk" and "produced butter", which represent quantitative performance indicators, but it should also be noted that only this information cannot be used to estimate the quality improvement rate and therefore the efficiency of the program.

The expected outcome and the performance indicator of the "Milk productionpromotion of realization" sub-program is - "Milk produced by farmers and agroentrepreneurs". This indicator repeats only the outcome and does not constitute a measure that would ensure the evaluation the efficiency of the results achieved within the subprogram.

The similar gaps are also in the formation of performance indicators in the Department of Tourism and Resorts of Autonomous Republic of Adjara.

In particular, in the sub-program "Marketing of the region as a tourist destination place on the international markets" measures to be taken to achieve the final result and the performance indicators are mixed. For example, the sub-program evaluation indicators are - "the amount of advertising/information materials" and "number of purchased promotional materials". These indicators do not allow to estimate the efficiency of the results achieved, as they are part of the action plan required to achieve the objectives set out within the subprogram, while "the number of unique online visitors in the target countries as a result of online advertising activities" is a quantitative evaluation indicator. Also the expected outcome of the program is formed incorrectly - "Advertising-marketing campaigns about the touristic potential of the region have been conducted in the target countries" - which is also the part of the action plan to achieve the objectives set out within the subprogram.

It must be noted that the program in 2015-2018 is characterized by the similar flaws, which shows the ignorance of the problem in previous years by the spending institutions.

The Department of Roads and Amelioration Systems Management of the Autonomous Republic of Adjara is implementing 2 main programs in 2015-2018 - "Roads and Amelioration Systems Management", which represents administrative costs and "Construction, rehabilitation and maintenance of road and amelioration infrastructure" which contains 5 sub-programs. 
In the process of evaluation of the programs revealed that the Department of Roads and Amelioration Systems Management does not determine the usefulness of the domestic roads, whereas does not have the opportunity to prove whether the best option is chosen during the periodic maintenance and rehabilitation works. Therefore, in order to increase the efficiency of the results achieved within each program/sub program, we think it is desirable that the Department of Roads and Amelioration Systems Management should work out and elaborate the evaluation mechanisms for the usefulness of roads before starting the work.

"Unfortunately, in some regions (Kakheti, Imereti, Samegrelo-Zemo Svaneti, Shida Kartli, Guria, Mtskheta-Mtianeti) the facts of budget failure and/or excessive performance are very common, which clearly indicates that incorrect forecasts are used while forming the plans. Frequently, The Basic Data and Directions Document does not correspond to the actual potential of the country's economy and the performance indicators in the program budget are general and do not estimate the effectiveness of the results" [1].

The discussion of the result-oriented budget is also interesting based on the international experience. Let's discuss several countries.

United Kingdom - The Public Service Agreements (PSA System), used since 1998, is designed to provide efficient financing. The main purpose of PSA system is to ensure transparency and accountability. Accordingly, the spending institutions are obliged to publish an annual plan of duties on the unified web-portal and the measures to be taken to achieve results indicating the funds allocated to them. So, if since 1990 the spending institutions were obliged to submit these reports once a year, since 2002 they are obliged to submit reports twice a year.

Australia - As a result of 1999-2000 reforms, Australia has moved into accrual budgeting, which significantly increased the quality of reporting on efficiency. The existing system of budgeting is oriented towards evaluation of achieved results and its goal is to improve the efficiency of resource spending and public accountability. Every institution is obliged to provide accurate and detailed information on the expected results and the performance indicators within the programs and sub-programs that estimate the results achieved with quantitative, qualitative, economic and efficiency characteristics.

Denmark - Denmark has the Effectiveness Contracts Policy according to which spending institutions are obliged to publish an annual report where will be presented the comparison between actual and expected results.

\section{Results}

The following results have been obtained during the research process:

1. In case of certain programs/sub-programs, despite the high rate of implementation there are still some flaws and low performance tendency. Specifically, some programs/sub-programs are characterized by low performance regarding to the adjusted plan, while concerning to the budget plan and cash execution they have a low implementation rate.

2. In some cases, some programs/sub-programs that are not planned by the Budget Law are being implemented.

3. Some programs/sub-programs have low performance regarding to the adjusted and approved plan and in some cases, resources are not spent at all which is another problem, as the credit resources consider the payment of a commitment fee on the unused part of the loan and increase the non-purpose expenditures.

4. The Annual Reporting on State Budget Execution does not include the information about all programs defined by the program budget. Therefore, it is impossible to 
evaluate how the goals set within the programs were achieved, which finally prevents to estimate the effectiveness of the program.

5. There are number of gaps in the formation of performance indicators for expected and final outcomes. In some cases, the indicators are irrelevant, incorrectly formulated or they are not a measure of effectiveness. Some programs and subprograms require additional indicators such as quantitative, qualitative, efficient, and productivity indicators in order to ensure that the expected results are correctly evaluated.

\section{Conclusions}

Based on the study and analysis of budgetary policy of Georgia, we have developed the following conclusions and recommendations.

Depending on the above mentioned flaws, we consider that budgetary organizations should pay attention to the distribution of funds between programs and subprograms in the budget planning process during the year and take into consideration the experience of previous years in order to avoid frequent, massive distribution of funds and zero or low performance of the programs/sub-programs. At the same time, it is important to maximize the effective use of credit resources with minimum expenses and avoiding the improper expenditures on the loan, for which we believe that it is appropriate to identify the timely interruptions of the project by the relevant agencies and timely implementation of effective measures to eliminate them.

Also, we consider that The Annual Reporting on State Budget Execution should include the information about all the programs defined by the program budget to evaluate the results achieved of the program within the budget allocations.

In our opinion, it is appropriate to correctly determine the final and intermediate results in the process of planning/implementation of programs/sub-programs, through which the budget performance indicators will be formed. In addition, it is important to use such indicators as quantitative, qualitative, efficient, and productivity in order to estimate correctly the final/intermediate results achieved within the programs/sub-programs.

\section{References}

1. G. Abuselidze, European Integration of Georgia and Financial-Economic Condition: Achievements and Challenges. European Journal of Sustainable Development, 8(1), 53-68 (2019)

2. G. Abuselidze, Analysis of the formation and use of budgetary policies ensuring the socio-economic development of territorial units. Economic Archive, 2 (2019)

3. G. Abuselidze, Areas of Improvement of Finance Policy in the Process of Advancing of Upgrading the Territorial Economic Activity and Financial Capacity. International Business Research, 6(5) (2013)

4. G. Abuselidze, Peculiarities of formation and functioning of Georgian budget system in transient period. Author's abstract of dissertation (2005)

5. M. Busso, J. Gregory, P. Kline, Assessing the incidence and efficiency of a prominent place-based policy. American Economic Review, 103(2), 897-947 (2013)

6. Budget Code of Georgia. Part III, Chapter V, Article 34; Clause 1 [online], Available at: https://matsne.gov.ge/ka/document/view/91006?publication=39 (2009)

7. G. Chakvetadze, T. Khetaguri, Result-oriented budgeting [online], Available at: https://sao.ge/files/kanonmdebloba/pubnication/biujetireba-2016.pdf (2015) 
8. M.V. Ehrlich, T. Seidel, The persistence effects of place-based policies. Evidence from the West-German Zonenrandgebiet. American Economic Journal: Economic Policy, forthcoming (2018)

9. E. Glaeser, J. Gottlieb, The economics of place-making policies. Brookings Papers on Economic Activity Spring, 155-253 (2008)

10. J. Kajaks, Economic and social situation in the Baltic States: Latvia. European Economic (2013)

11. P. Kline, E. Moretti, Local economic development, agglomeration economies and the big push: 100 years of evidence from the Tennessee Valley Authority. Quarterly Journal of Economics, 129(1), 275-331 (2014)

12. Ministry of Finance and Economy of Autonomous Republic of Adjara. The Program Budget [online], Available on: https://matsne.gov.ge/document/view/2605063?publication=2 (2015).

13. Ministry of Finance and Economy of Autonomous Republic of Adjara. The Program Budget [online], Available https://matsne.gov.ge/document/view/3108436?publication=2 (2016)

14. Ministry of Finance and Economy of Autonomous Republic of Adjara. The Program Budget [online], Available https://matsne.gov.ge/document/view/3515842?publication=2 (2017)

15. Ministry of Finance and Economy of Autonomous Republic of Adjara. The Program Budget [online], Available at: https://matsne.gov.ge/document/view/3950679?publication=2 (2018)

16. Ministry of Finance and Economy of Autonomous Republic of Adjara. The Republican Budget [online], Available at: http://adjara.gov.ge/uploads/Docs/a3c4b20dbe5a4113982b4b3eb550.pdf (2015)

17. Ministry of Finance and Economy of Autonomous Republic of Adjara. The Republican Budget [online], Available http://adjara.gov.ge/uploads/Docs/bfedcf60982a4e6ab9dda85f739a.pdf (2016)

18. Ministry of Finance and Economy of Autonomous Republic of Adjara. The Republican Budget [online], Available http://adjara.gov.ge/uploads/Docs/cef43c2608eb4b2dbd749b810162.pdf (2017)

19. Ministry of Finance and Economy of Autonomous Republic of Adjara. The Republican Budget [online], Available http://adjara.gov.ge/uploads/Docs/0e4093bbbf75430fb867666f1690.pdf (2018)

20. Ministry of Finance and Economy of Autonomous Republic of Adjara. Annual Execution Report of Republican Budget [online], Available at: http://adjara.gov.ge/branches/listpage.aspx?pid=174\&gid=5\&ppid=162 (2015-2018)

21. Ministry of Finance of Georgia. Approval of the methodology for drawing up the program budget, Order N385. [online], Available at: https://matsne.gov.ge/ka/document/view/1400751?publication=0 (2011)

22. Ministry of Finance of Georgia. Annual Report on the State Budget of Georgia [online], Available at: http://www.parliament.ge/ge/ajax/downloadFile/32787/\%E1\%83\%90\%E1\%83\%9C\% E1\%83\%92\%E1\%83\%90\%E1\%83\%A0\%E1\%83\%98\%E1\%83\%A8\%E1\%83\%98 (2014)

23. Ministry of Finance of Georgia. Annual Report on the State Budget of Georgia [online], Available at: http://parliament.ge/ge/ajax/downloadFile/46937/07- 
$2.494 \% \mathrm{E} 1 \% 83 \% 90 \% \mathrm{E} 1 \% 83 \% 9 \mathrm{C} \% \mathrm{E} 1 \% 83 \% 92 \% \mathrm{E} 1 \% 83 \% 90 \% \mathrm{E} 1 \% 83 \% \mathrm{~A} 0 \% \mathrm{E} 1 \% 83$ $\% 98 \% \mathrm{E} 1 \% 83 \% \mathrm{~A} 8 \% \mathrm{E} 1 \% 83 \% 98$ (2015)

24. Ministry of Finance of Georgia. Investment projects of the state budget of 2016 financed by donor organizations [online], Available at: https://mof.ge/shesrulebis angarishi_2016 12tve (2016)

25. Ministry of Finance of Georgia. Annual Report on the State Budget of Georgia [online], Available

at: http://parliament.ge/ge/ajax/downloadFile/95078/\%E1\%83\%90\%E1\%83\%9C\%E1\%83 \%92\%E1\%83\%90\%E1\%83\%A0\%E1\%83\%98\%E1\%83\%A8\%E1\%83\%98 2017 \%E 1\%83\%91\%E1\%83\%98\%E1\%83\%A3\%E1\%83\%AF\%E1\%83\%94\%E1\%83\%A2\%E1 \%83\%98 (2017)

26. Ministry of Finance of Georgia. Investment projects of the state budget of 2016 financed by donor organizations [online], Available at: https://mof.ge/images/File/biujeti-2018-12tve/sainvesticio.pdf (2018)

27. Real Estate Investment Blog. The economy in the Baltic states keeps growing and here's why [online], Available at: https://blog.reinvest24.com/2019/the-economy-inthe-baltic-states-keeps-growing-and-heres-why/ (2019)

28. A. Rodríguez-Pose, The revenge of the places that don't matter (and what to do about it). Cambridge Journal of Regions, Economy and Society, 11(1), 189-209 (2018)

29. K. Staehr, Public Finances and Fiscal Policy in the Baltic States 1991-2015. Research in Economics and Business: Central and Eastern Europe, 8(1), 26-41 [online], Available at: http://rebcee.eu/index.php/REB/article/viewFile/73/59 (2016)

30. K. Staehr, Austerity in the Baltic states during the global financial crisis [online], Available at: https://archive.intereconomics.eu/year/2013/5/austerity-in-the-balticstates-during-the-global-financial-crisis/ (2013)

31. State Audit Office Report on "2014 Georgia's State Budget Execution Annual Report." [online], Available at: https://sao.ge/files/auditi/2014-biujetis-cliuri-shesrulebisshesaxeb-moxseneba-new.pdf (2014)

32. State Audit Office Report on "2015 Georgia's State Budget Execution Annual Report." [online], Available at: https://sao.ge/files/auditi/2015-clis-sax-biujet-shesrulebis-wliuriangarishi.pdf (2015)

33. State Audit Office Report on "2016 Georgia's State Budget Execution Annual Report." [online], Available at: https://sao.ge/files/auditi/moxseneba-2016-biujetis-shesrulebiscliuri-angarishis-shesaxeb.pdf (2016)

34. State Audit Office Report on "2017 Georgia's State Budget Execution Annual Report." [online], Available at: https://sao.ge/files/auditi/moxseneba-sakartvelos-2017-clissaxelmcio-biujet.pdf (2017)

35. State Audit Office Report on "2018 Georgia's State Budget Execution Annual Report." [online], Available at: https://sao.ge/files/auditi/mokhseneba-2018biujetis\%20shesruleba.pdf (2018)

36. Swedbank. Macro Focus, The temperature is slowly rising in the Baltic States [online], Available at: https://www.swedbank-research.com/english/macro focus/2018/18-1001/macro_focus economy heat_index_final.pdf (2018)

37. The Government of Georgia. Basic Data and Directions Document for 2018-2021 [online], Available at: https://mof.ge/images/File/BDD/2018-2021/saboloo/BDD-20182021-29.01.2018-saboloo.pdf (2018) 